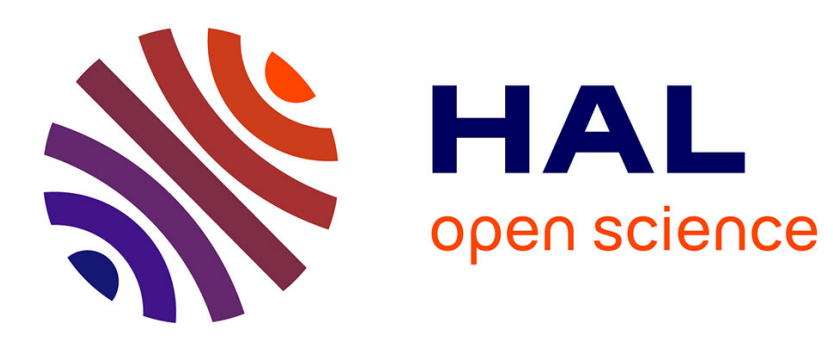

\title{
Does carbon dioxide storage by cyanobacteria induce biomineralization in presence of basaltic glass?
} Thomas Ferrini, Olivier Grandjouan, Olivier Pourret, Raul E Martinez

\section{To cite this version:}

Thomas Ferrini, Olivier Grandjouan, Olivier Pourret, Raul E Martinez. Does carbon dioxide storage by cyanobacteria induce biomineralization in presence of basaltic glass?. Geochemical Journal -Japan-, 2021, 55 (2), pp.51-58. 10.2343/geochemj.2.0617 . hal-03085925

\section{HAL Id: hal-03085925 https://hal.science/hal-03085925}

Submitted on 22 Dec 2020

HAL is a multi-disciplinary open access archive for the deposit and dissemination of scientific research documents, whether they are published or not. The documents may come from teaching and research institutions in France or abroad, or from public or private research centers.
L'archive ouverte pluridisciplinaire HAL, est destinée au dépôt et à la diffusion de documents scientifiques de niveau recherche, publiés ou non, émanant des établissements d'enseignement et de recherche français ou étrangers, des laboratoires publics ou privés. 
5 Thomas Ferrini ${ }^{1}$, Olivier Grandjouan ${ }^{1}$, Olivier Pourret ${ }^{1, \#}$, Raul E. Martinez ${ }^{2, *}$

6

7

8

9

\section{biomineralization in presence of basaltic glass? \\ biomineralization in presence of basaltic glass?}

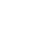

${ }^{1}$ UniLaSalle, AGHYLE, 19 rue Pierre Waguet, 60026 Beauvais cedex, France

${ }^{2}$ Institut für Geowissenschaten, Universität Freiburg, Alberstraße 23b, 79104 Freiburg,

Germany

Does carbon dioxide storage by cyanobacteria induce 


\section{Abstract}

Cyanobacteria induced biomineralization of atmospheric $\mathrm{CO}_{2}$ is a natural process leading to the

formation of carbonates by spontaneous precipitation or through the presence of nucleation sites, under supersaturated conditions. As importance of basaltic rocks in the carbon cycle has already been highlighted, basaltic glass was chosen to test its ability to release cations needed for carbonate formation in presence of Synechococcus sp. cyanobacteria. Active cyanobacteria were expected to generate a local alkaline environment through photosynthetic metabolism. This process produces oxygen and hydroxide ions as waste products, raising the $\mathrm{pH}$ of the immediate cell surface vicinity and indirectly enhancing the carbonate $\mathrm{CO}_{3}{ }^{2-}$ concentration and providing the a degree of saturation that can lead to the formation of calcite $\mathrm{CaCO}_{3}$ or magnesite $\mathrm{MgCO}_{3}$. In the presence of active cells, the saturation index (SI) increased from -10.56 to -9.48 for calcite and from -13.6 to -12.5 for magnesite, however they remained negative due to the low $\mathrm{Ca}^{2+}$ and $\mathrm{Mg}^{2+}$ activities. Dead cells were expected to act as nucleation sites by the stepwise binding of carbonate with $\mathrm{Ca}^{2+}$ and $\mathrm{Mg}^{2+}$ on their surface. In the presence of inactive cells, SI values were closer to 0 but still negative due to the low $\mathrm{pH}$ and cation concentrations. Our results highlight that our current understanding of the carbon cycle suggests that Earth's climate is stabilized by a negative feedback involving $\mathrm{CO}_{2}$ consumption and especially during chemical weathering of silicate minerals.

Keywords: biomineralization, cyanobacteria, basaltic glass, carbonate, saturation index, critical zone 


\section{Introduction}

The rise of $\mathrm{CO}_{2}$ concentrations in the atmosphere is one of the most important environmental problems on Earth today arising from anthropic activity (Gerlach, 2011). Carbon storage methods, or carbon concentration mechanisms (CCM), need to be developed urgently in order to reduce the $\mathrm{CO}_{2}$ impact on Earth's terrestrial and aquatic environments. The ability of cyanobacteria to induce the biomineralization of $\mathrm{CO}_{2}$ is an option which is still in its infancy and could possibly be used in the near-future to decrease atmospheric $\mathrm{CO}_{2}$ levels (Martinez et al., 2016). Previous studies have proven the link between cyanobacteria photosynthesis and the presence of metallic cations could lead to carbonate precipitation in the presence of atmospheric $\mathrm{CO}_{2}$ and under suitable solution conditions (Jansson and Northen, 2010; Martinez et al., 2016; Obst et al., 2009).

Photosynthesis and $\mathrm{CCM}$ are the first steps to biomineralization of $\mathrm{CO}_{2}$. Cyanobacteria are autophototrophic microorganisms. They are primary producers, which generate their own nutrients by carrying out the oxygenic photosynthesis (Martinez et al., 2016). This metabolism needs carbon as a source of inorganic carbon in the form of dissolved $\mathrm{CO}_{2}$, natural light as source of energy and water to provide electrons needed in the redox transformation of carbon (Schubert et al., 1997). The Calvin-Benson cycle permits the assimilation of the inorganic carbon thanks to the initial $\mathrm{CO}_{2}$-fixing-enzyme of photosynthesis: RuBisCO (Ribulose Biphosphate Carbolxylase Oxygenase) (Fridlyand and Scheibe, 1999; Spreitzer and Salvucci, 2002). Chemical and photochemical reactions take place in photosystems located on the thylakoid membrane of the cyanobacteria cell. ATP (Adenosine triphosphate) and NADPH (Nicotinamide adenine dinucleotide phosphate) are chemical substances which permit $\mathrm{CO}_{2}$ assimilation. A constant supply of inorganic carbon (IC) is required to carry out photosynthesis. 
Dissolved $\mathrm{CO}_{2}$, in the form of bicarbonate $\mathrm{HCO}_{3}{ }^{-}$is the inorganic form of carbon used by cyanobacteria as an IC source. A metabolic system is used to attain inorganic carbon from the aqueous environment. The CCM corresponds to an environmental adaptation of cyanobacteria, it allows IC incorporation inside the cell in the form of $\mathrm{HCO}_{3}{ }^{-}$and convert it to $\mathrm{CO}_{2}$ (Price et al., 2008). Molecules are attracted and stocked inside the cell with the help of IC transporters located in both plasma and outer membranes. $\mathrm{HCO}_{3}{ }^{-}$transport is enhanced by the extra-ATP generated during photosynthesis. The inorganic carbon is transported into the bacterial microcompartment where the bicarbonate molecules are transformed into $\mathrm{CO}_{2}$ by the enzyme carbonic anhydrase. The remaining $\mathrm{CO}_{2}$ is then assimilated by the enzyme RuBisCO for photosynthesis (Figure 1). A proton $\mathrm{H}^{+}$is consumed by each of these reactions, leading to the release of a hydroxide ion $\left(\mathrm{OH}^{-}\right)$outside the cell as a waste product along with $\mathrm{O}_{2}$. This allows the generation of an alkaline $\mathrm{pH}$ within the micro-environment around the cyanobacteria cell. This alkaline $\mathrm{pH}$ permits the deprotonation of the external bicarbonate $\mathrm{HCO}_{3}{ }^{-}$to carbonate ions $\mathrm{CO}_{3}{ }^{2}$. The presence of both metal cations (e.g. $\left.\mathrm{Ca}^{2+} / \mathrm{Mg}^{2+}\right)$ and carbonate $\left(\mathrm{CO}_{3}{ }^{2-}\right)$ allows the nucleation of carbonates in the form of calcite $\left(\mathrm{CaCO}_{3}\right)$ and magnesite $\left(\mathrm{MgCO}_{3}\right)$ (Martinez et al., 2016; Riding, 2006). However, the amount of metal cations and carbonate must be high enough to reach supersaturation with respect to these carbonate minerals.

In this study, basaltic glass was chosen as a source of metallic cations due to its composition and abundance on the Earth's surface. Its importance in the carbon cycle has been proven on several previous studies (Dessert et al., 2003; Grimm et al., 2019; Schlesinger and Bernhardt, 2013; Schott et al., 2012). A high rate of dissolution of basaltic glass would be required to release significant metallic cation concentrations to achieve supersaturation with respect to carbonate phases. Varying an electrolyte $\mathrm{NaNO}_{3}$ background concentration has been shown to affect the process of simple silicate mineral dissolution and the rate of release of metallic cations as well as their activity (Martinez et al., 2014; Martinez et al., 2016). An 
optimal concentration is needed in order to reach $\mathrm{Ca}^{2+}$ and $\mathrm{Mg}^{2+}$ activities, which together with carbonate ion activities would lead to precipitation of carbonates. The Synechococcus cyanobacteria species chosen for this study is representative of seawater cyanobacteria as along with Prochloroccocculs sp., it is responsible for approximately $30 \%$ of the photosynthesis on Earth. Synechococcus sp. is a unicellular coccoid cyanobacteria containing outermost surface layers but no cell covering sheath (Martinez et al., 2010; Martinez et al., 2008). The goal of this study is to determine whether basaltic glass is an efficient source of metal cations needed for $\mathrm{CO}_{2}$ mineralization and then to quantify the rates of carbonate precipitation in presence of this primary silicate and Synechococcus cyanobacteria species so that optimal conditions in terms of basaltic glass dissolution and cyanobacteria biomass can be found.

\section{Material and methods}

A $20 \mathrm{~mL}$ aliquot of active Synechococcus sp. cyanobacteria stock at the stationary phase was placed in a 5 L Schott@ bottle. Synechococcus sp. cultures were grown in Cyanobacteria BG11 Freshwater Medium (Sigma-Aldrich C3061) for three weeks to stationary growth phase (Martinez et al., 2010). Active cyanobacteria stocks were prepared in order to achieve photosynthesis in presence of basaltic glass (see bulk composition in Table 1), in order to quantify the influence of cyanobacteria on the dissolution of the mineral could be observed and the supersaturation conditions reached (see discussion on choice of experimental conditions in Martinez et al., 2010). Stock cultures of cyanobacteria were kept at room temperature $\left(23 \pm 1^{\circ} \mathrm{C}\right)$ under constant cool white fluorescent light illumination (5000 lx) and a constant filtered air injection (3 L/min at around $400 \mathrm{ppm}$ ) in order to provide cyanobacteria with needed inorganic carbon. The air inflow was used to keep the culture in a constant movement needed for optimal growth. For each experiment, $5 \mathrm{~L}$ of 1/500 diluted cyanobacteria growth medium inoculated 
with a $20 \mathrm{~mL}$ aliquot of regular 1/50 BG-11 (Table 2) cyanobacteria stock was placed on a rotary shaker at $250 \mathrm{rpm}$ (Martinez et al., 2008). Dead cyanobacteria were prepared by autoclaving an aliquot of active stock at $121^{\circ} \mathrm{C}$ for $20 \mathrm{~min}$. To measure the exact cyanobacteria mass, a $25 \mathrm{~mL}$ sample was collected. Vacuum filtration was used to filter the sample through a $0.2 \mu \mathrm{m}$ pore size cellulose nitrate filter (Whatman $\left.{ }^{\circledR}\right)$. The filtered sample was placed in an oven at $60^{\circ} \mathrm{C}$ for $30 \mathrm{~min}$ and then weighed.

\subsection{Flow through open reactors system experimental design}

Basaltic glass dissolution experiments were performed at $23 \pm 1^{\circ} \mathrm{C}$ by mixing two different stock solutions in flow through reactors with a peristaltic pump with a fixed inflow rate of $1.4 \mu \mathrm{L} / \mathrm{min}$. The active cyanobacteria and inorganic stocks solutions used are described in Tables $\mathbf{2}$ and $\mathbf{3 .}$

To quantify the rates of basaltic glass and carbonate precipitation in presence of Synechococcus $s p$. cyanobacteria, duplicate flow through reactors were used, each connected to the inorganic and active cyanobacteria stocks by a peristaltic pump (Active cyanobacteria Flow Through open reactor, AFT; Table 2 and Figure 2).

To assess the role of bio-mineralization by dead cells, a calcium chloride stock solution was used instead of basaltic glass as the source of metal cations (e.g. $\mathrm{Ca}^{2+}$ ). For these experiments, a flow through reactor was connected through the peristaltic pump to both the calcium chloride and dead cyanobacteria stocks previously washed by centrifuging at $10,000 \mathrm{rpm}$ for $20 \mathrm{~min}$ (Calcium Flow Through reactor, CFT; Table 3 and Figure 3). Preliminary results and tests are available in Ferrini and Grandjouan (2015). These dead cells act as nucleation sites. They 
decrease the activation energy for precipitation, but saturation index (SI) values are not influenced by the existence of nucleation sites (Martinez et al., 2008).

For all experiments, Tygon R 3603 tubes were used to link both stocks to $200 \mathrm{~mL}$ flow through reactors with the help of a 4 channel peristaltic pump with a low flow rate of $1.4 \mu \mathrm{L} / \mathrm{min}$.

\subsection{Sample analysis}

In order to monitor the chemical evolution and the cyanobacteria biomass concentration of the solution inside the flow through reactor, the $\mathrm{pH}$, conductivity, alkalinity, optical density, and $\mathrm{Ca}^{2+}$ and $\mathrm{Mg}^{2+}$ concentrations were measured from samples collected in $50 \mathrm{~mL}$ polypropylene Falcon ${ }^{\circledR}$ tubes from the output of the flow through reactors, once daily. Time zero was taken to be the time of this first sampling of the flow through reactor solution (Martinez et al., 2016). Reactors were placed in a water bath at $22^{\circ} \mathrm{C}$ in order to keep their contents solutions at a constant temperature. A $20 \mathrm{~mL}$ sample was taken from each reactor for all experiments. An aliquot of $7 \mathrm{~mL}$ of sample was used to measure the optical density of the solution at $750 \mathrm{~nm}$ wavelength, to approximate the concentration of cyanobacteria biomass over time. The remaining $13 \mathrm{~mL}$ were used to measure $\mathrm{pH}$, total alkalinity and conductivity. The $\mathrm{pH}$ and alkalinity were measured with an automatic titration system (Metrohm® 719 Titrino automatic titrator). In this study, dominated by the presence of dissolved $\mathrm{CO}_{2}$, the total alkalinity (TA) provides an estimate of the concentrations of bicarbonate and carbonate species in solution. The TA is determined through an acid titration (alkalinity titration) where the final concentration of the acid, at the second end-point of the carbonate system, $\mathrm{pH}=4.3$, represents the total alkalinity of the solution. Carbonate alkalinity (CA) is determined by driving the alkalinity titration to the 
first end-point for the carbonate system at $\mathrm{pH}=8.3$. From the carbonate alkalinity, the $\mathrm{CO}_{3}{ }^{2-}$ concentration in solution, which is part of total alkalinity, can be determined:

$$
\mathrm{TA}=\left[\mathrm{HCO}_{3}^{-}\right]+2\left[\mathrm{CO}_{3}^{2^{-}}\right]+\left[\mathrm{OH}^{-}\right]-\left[\mathrm{H}^{+}\right] \quad(\mathrm{la})
$$

$$
\mathrm{CA}=2\left[\mathrm{CO}_{3}^{2-}\right]+\left[\mathrm{OH}^{-}\right] \quad(\mathrm{lb})
$$

As $\left[\mathrm{CO}_{3}{ }^{2-}\right],\left[\mathrm{H}^{+}\right]$and $\left[\mathrm{OH}^{-}\right]$are negligible for neutral to alkaline $\mathrm{pH}$ conditions (between 6 and 11), total alkalinity can be re-defined to:

$$
\mathrm{TA}=\left[\mathrm{HCO}_{3}^{-}\right]
$$

$\mathrm{Ca}^{2+}$ and $\mathrm{Mg}^{2+}$ concentrations were measured by flame atomic adsorption spectroscopy (FAAS) with an Analytik Jena Vario 6 flame atomic adsorption spectrometer. The conductivity of sample aliquots was measured using a WTW LF 325 conductivity meter where conductivity is measured in $\mathrm{mS} / \mathrm{cm}$ (Harris, 2010). Conductivity measurements for a particular solution allow calculation of the ionic strength (IS). The IS is proportional to the concentration of all dissolved salts in a solution. The ionic strength is required to calculate cation activity (ac) as shown below:

$$
\mathrm{aC}_{\mathrm{C}}=[\mathrm{C}] \gamma_{\mathrm{C}}
$$

where $[\mathrm{C}]$ is the species concentration and $\gamma_{C}$ is the activity coefficient. The $\log _{10}$ of $\gamma_{C}$ can be calculated as per the Debye-Hückel equation Eq. 4 as a function of the solution IS determined from conductivity measurements:

$$
\log \gamma_{C}=\left(-0.51 * z^{2 *} \sqrt{I S}\right) /\left(1+\left(\alpha^{*} \sqrt{ } I S / 305\right)\right)
$$

where $\mathrm{z}$ represents the charge of the ion (e.g. for $\mathrm{Mg}^{2+}, \mathrm{z}=2$ ), $\alpha$ the radius of the ion in picometers (e.g. for $\mathrm{Ca}^{2+}, \alpha_{\mathrm{Ca} 2+}=600 \mathrm{pm}$ ) (Harris, 2010; Stumm and Morgan, 1996). 
189 To predict the formation of carbonate phases in this study, it is first necessary to quantify the 190 degree of solution supersaturation with respect to $\mathrm{Ca}$ or $\mathrm{Mg}$ carbonates. This requires 191 knowledge of the saturation index for each of these mineral phases. However, calculation of 192 saturation state is first necessary. The saturation state $(\Omega)$ represents the degree of saturation of 193 a solution with respect to a particular mineral phase (Langdon et al., 2000) and is defined as 194 follows:

$$
\Omega=\left(a \mathrm{Ca}^{2+*} a \mathrm{CO}_{3}{ }^{2-}\right) / \mathrm{Ksp}
$$

196 Where Ksp is the solubility product of the mineral phase that can potentially form in solution 197 (e.g. for calcite, $\mathrm{Ksp}=10^{-8.48}$ ) and, $\mathrm{aCa}^{2+}$ and $\mathrm{aCO}_{3}{ }^{2-}$ are the activities of $\mathrm{Ca}^{2+}$ and $\mathrm{CO}_{3}{ }^{2-}$ 198 respectively. The SI is then defined as:

$$
S I=\log _{10}(\Omega)
$$

A positive value of SI indicates supersaturation with respect to a mineral phase and suggests that precipitation of the mineral would occur. However this depends further on solution conditions (e.g. mineral nucleation, spontaneous nucleation/precipitation) (Langdon et al., 2000). 


\section{Results}

Temporal evolution of the $\mathrm{pH}$, the total alkalinity and the cations concentrations has been measured. These values were used to calculate saturation index with respect to calcite and magnesite. Related values for AFT and CFT are presented in Figures 4 and 5 and Figures 6 and 7, respectively. For all conditions, experiments were carried out in duplicates.

\subsection{Active cyanobacteria Flow Through open reactor results}

In this experiments, the $\mathrm{pH}$ remained alkaline, starting at $10.9 \pm 1$ and declining until a $\mathrm{pH}$ of both reactors (Figure 4). $\left[\mathrm{Ca}^{2+}\right]$ and $\left[\mathrm{Mg}^{2+}\right]$ remained constant for the duration of the experiments at an average of $3.37+/-1.00 \mathrm{mg} / \mathrm{L}$ for $\left[\mathrm{Ca}^{2+}\right]$ and $3.28+/-0.44 \mathrm{mg} / \mathrm{L}$ for $\left[\mathrm{Mg}^{2}\right]$. A slight decrease in these concentrations was observed for the experiment in the first reactor. SI values for both calcite and magnesite remained negative for the time of the experiment. The $\mathrm{SI} \mathrm{I}_{\text {(calcite) }}$ increased from -10.6 to -9.4 over a period of $145 \mathrm{~h}$ whereas the $\mathrm{SI}_{\text {(magnesite) }}$ raised from -13.6 to -12.5 (Figure 5). Both SI curves reached a constant threshold at $150 \mathrm{~h}$.

\subsection{Calcium Flow Through reactor results}

The $\mathrm{pH}$ and the total alkalinity increased through the $300 \mathrm{~h}$ of the experiments. A total alkalinity of $0.2 \mathrm{mmol} / \mathrm{L}$ was recorded at the start of experiments to reach a final value of $0.75 \mathrm{mmol} / \mathrm{L}$ (Figure 6). The $\mathrm{pH}$ was for the most part neutral but raised from 6.3 to a last value of 6.75 
228 (Figure 6). The calcium chloride used permitted to obtain a rather constant $\left[\mathrm{Ca}^{2+}\right]$ concentration 229 at an average of $280 \mathrm{mg} / \mathrm{L}$. The calculated $\mathrm{SI}_{\text {(calcite) }}$ is negative but close to the solution 230 supersaturation with respect to calcite. These values are remained within the range of -4.6 to 2314.9 for the duration of the experiment (Figure 7).

232 


\section{Discussion}

None of both experiments could achieve supersaturation state with respect to calcite or magnesite. The SI remain negative but fluctuate as a function of the $\mathrm{pH}$, the cation concentration and the total alkalinity. This confirms that saturation index depends on metal cations and $\mathrm{CO}_{3}{ }^{2-}$ activities and further suggests the inability of basaltic glass dissolution to provide the necessary amount of cations required for solution supersaturation with respect to carbonates. The AFT experiment shows constant $\left[\mathrm{Ca}^{2+}\right]$ and $\left[\mathrm{Mg}^{2}\right]$ concentrations (see details in Ferrini and Grandjouan (2015) ). In this case an increase in the $\mathrm{CO}_{3}{ }^{2-}$ activity would be required to achieve supersaturated conditions with respect to carbonate, this would be reflected in a positive value of the SI for these mineral phases. As the concentration of cations remained constant, a higher concentration of carbonate or a higher degree of bicarbonate deprotonation from a higher $\mathrm{pH}$ would be required. This means an enhanced deprotonation of bicarbonate $\mathrm{HCO}_{3}{ }^{-}$and the consumption of hydroxide ion $\left(\mathrm{OH}^{-}\right)$. This then explains the decreasing $\mathrm{pH}$ and the increasing total alkalinity as per eq.1. According to the previously mentioned definition of the carbonate alkalinity a $\mathrm{pH}$ higher than 8.3 would be required in order to induce bicarbonate ion deprotonation for production of $\mathrm{CO}_{3}{ }^{2-}$ in significant concentrations (Stumm and Morgan, 1996).

A higher $\mathrm{pH}$ could be reached by active cyanobacteria. Indeed, cyanobacteria consume bicarbonate ions by photosynthesis which leads to the higher $\mathrm{pH}$ values, the formation of carbonate $\left(\mathrm{CO}_{3}{ }^{2-}\right)$ and a raising $\mathrm{SI}$ in the presence of sufficient metal cations for supersaturation In the CFT case, increasing $\mathrm{pH}$ rates can be explained by the presence of dead cyanobacteria mass and their interaction of their deprotonated cell surface groups with dissolving $\mathrm{CO}_{2}$ from air injection (Weber and Martinez, 2017). However, SI remains negative because of the nearneutral $\mathrm{pH}$ which prevents calcite precipitation as bio-mineralization needs a $\mathrm{pH}$ higher than 8.3 to commence the generation of carbonate ions. 
It has been shown that active cyanobacteria have a protective mechanism against carbonate precipitation on their surface, which is missing for dead cyanobacteria implying that this is the consequence of the metabolic activity of these primary producers (Martinez et al., 2010; Martinez et al., 2008). Dead cyanobacteria cells or cellular debris may act as nucleation sites by binding $\mathrm{Ca}^{2+}$ and $\mathrm{Mg}^{2+}$ cations on their surface. This could explain why the SI results become less negative in the CFT experiment in presence of dead cells. There are two mechanisms of mineral precipitation which are favored depending on the degree of solution supersaturation with respect to a particular mineral. In our study, we did not observe supersaturation with respect to carbonate minerals, nor the conditions for spontaneous nucleation of these minerals, a process that takes place saturation state values equal or in excess of 3 to 4 . However, the existence of nucleation sites, does decrease the activation energy for precipitation, therefore affecting the saturation index for a particular mineral, not in the bulk solution, but in the microenvironment of dead cell surfaces, for example, where the value of the SI for a specific carbonate mineral may be enhanced due to the higher concentration of metal cations and carbonate, near the negatively charged reactive solid surface. Therefore, the presence of both active and dead cyanobacteria, as in the natural environment, contributes to controlling the mode of carbonate mineral precipitation, through the generation of an alkaline $\mathrm{pH}$ or due to the efficient sorption of metal cations leading to the nucleation of mineral phases (Martinez et al., 2010; Martinez et al., 2016; Weber and Martinez, 2017).

Another important factor which is needed for supersaturation is the metal cations concentrations. CFT results proved that high metal cation concentrations from an efficiently dissolving source, such as calcium chloride, lead to SI values which are closer to solution supersaturation with respect to carbonates. AFT $\left[\mathrm{Ca}^{2+}\right]$ and $\left[\mathrm{Mg}^{2+}\right]$ concentrations from basaltic glass dissolution were insufficient to achieve carbonate precipitation. Indeed, a solution needs to be supersaturated with respect to a particular mineral in order for it to precipitate. Therefore, 
the precipitation of carbonate minerals will depend not only on the metal cation activity but also on the carbonate activity. In our results the $\mathrm{pH}$ of the solutions was low, therefore we observed a low carbonate activity and a slight release of metal cations from the basaltic glass. Therefore, both of these aspects did not allow the ion activity product of metal cation and carbonate in solution, to exceed the solubility product for carbonate minerals. This implies that the use of basaltic glass for carbonation and $\mathrm{CO}_{2}$ mineralization would be inefficient if employed at large scale, requiring the use of faster dissolving simple silicate minerals such as olivine, or finding a way to enhance the release of metal cations from simple and more complicated alumino-silicate minerals. The slight decrease in metal cation concentrations in these experiments, occasionally observed, can be explained by the need for more testing and development of the flow through reactor used, where a fast flow rate would cause dilution of metal cations. A slower pump rate would have to be used. Moreover, higher metal cation dissolution rates would have to be reached, however, another silicate mineral would need to be tested which can release metal cations at a faster rate. The background electrolyte concentration of $0.04 \mathrm{~mol} / \mathrm{L} \mathrm{NaNO}_{3}$ could be modified in order to find the optimal concentration and optimize the dissolution rate and the metal cation activities. Smaller basaltic glass particles can be used, this would produce and increase mineral surface area which would lead to an increase in the basaltic glass dissolution rate.

As proposed on Figure 1, parameters which could contribute to achieving supersaturation state with respect to carbonates and subsequent precipitation in the presence of cyanobacteria are highlighted. As evidenced by our study, several points have to be improved in order to achieve carbonate nucleation and precipitation. Synechococcus cyanobacteria have to be grown in proper conditions with enough space and time to get to cell population saturation (at least 2 weeks). Active cells lead to an alkaline (high $\mathrm{pH}$ ) environment by the photosynthesis process, and indirectly to the formation of carbonate $\mathrm{CO}_{3}{ }^{2-}$. The "flow through reactor" open system 
permits a constant $\mathrm{CO}_{2}$ supply and other nutrients required for photosynthesis and cell growth.

309 On another hand, basaltic glass has to be dissolved in optimal conditions so as to reach high aqueous $\left[\mathrm{Ca}^{2+}\right]$ and $\left[\mathrm{Mg}^{2+}\right]$ concentrations. Providing all these conditions, calcite or magnesite precipitation could be expected in the flow through reactors. Using the rate model in Eq.11 an approximation of the total carbonate precipitation amount could be calculated for potential implementation of these systems at the larger scale. Scanning electron microscopy and energydispersive X-ray spectroscopy analyses could then help to the analysis and identification of carbonates to confirm the presence of calcite or aragonite polymorphs or that of magnesite. By finding optimal conditions for cyanobacteria induced bio-mineralization, this method could be used to stock significant quantities of $\mathrm{CO}_{2}$ at a large scale.

Overall, our results highlight that our current understanding of the long-term carbon cycle suggests that Earth's climate is stabilized by a negative feedback involving $\mathrm{CO}_{2}$ consumption and especially during chemical weathering of silicate minerals (Penman et al., 2020).

\section{Acknowledgments}

The authors would like to thank the Institut Polytechnique UniLaSalle, for funding part of this study and T.F. and O.G. bachelor thesis. In addition the authors would like to thank Ms. Sigrid Hirth-Walther of the Institute of Geosciences at the University of Freiburg for F-AAS measurements, Dr. Petru Jitaru of Institut Polytechnique UniLaSalle for ICP-MS analysis. Furthermore, the authors would like to extend their gratitude to Dr. Christian Grimm and Dr.

Eric H. Oelkers of the GET-CNRS in Toulouse, France, for providing the basaltic glass samples used in this study. Eventually, we thank Dr. Daniel E. Ibarra for insightful review of the manuscript. 
Dessert, C., Dupré, B., Gaillardet, J., François, L. M. and Allègre, C. J. (2003) Basalt weathering laws and the impact of basalt weathering on the global carbon cycle. Chem. Geol. 202, 257-273.

Ferrini, T. and Grandjouan, O. (2015) $\mathrm{CO}_{2}$ storage by cyanobacteria induced biomineralization in presence of basaltic glass. Bachelor.

Fridlyand, L. E. and Scheibe, R. (1999) Regulation of the Calvin cycle for CO2 fixation as an example for general control mechanisms in metabolic cycles. Biosystems. 51, 79-93.

Gerlach, T. (2011) Volcanic versus anthropogenic carbon dioxide. Eos, Transactions American Geophysical Union. 92, 201-202.

Grimm, C., Martinez, R. E., Pokrovsky, O. S., Benning, L. G. and Oelkers, E. H. (2019) Enhancement of cyanobacterial growth by riverine particulate material. Chem. Geol. 525, 143-167.

Harris, D. C. (2010) Quantitative Chemical Analysis, Eight Edition. MacMillan Publishing

Jansson, C. and Northen, T. (2010) Calcifying cyanobacteria - the potential of biomineralization for carbon capture and storage. Current Opinion in Biotechnology. 21, 365-371.

Langdon, C., Takahashi, T., Sweeney, C., Chipman, D., Goddard, J., Marubini, F., Aceves, H., Barnett, H. and Atkinson, M. J. (2000) Effect of calcium carbonate saturation state on the calcification rate of an experimental coral reef. Global Biogeochem. Cy. 14, 639-654.

Martinez, R. E., Gardés, E., Pokrovsky, O. S., Schott, J. and Oelkers, E. H. (2010) Do photosynthetic bacteria have a protective mechanism against carbonate precipitation at their surfaces? Geochim. Cosmochim. Acta. 74, 1329-1337.

Martinez, R. E., Pokrovsky, O. S., Schott, J. and Oelkers, E. H. (2008) Surface charge and zeta-potential of metabolically active and dead cyanobacteria. J. Colloid Interface Sci. 323, 317-325.

Martinez, R. E., Weber, S. and Bucher, K. (2014) Quantifying the kinetics of olivine dissolution in partially closed and closed batch reactor systems. Chem. Geol. 367, 1-12.

Martinez, R. E., Weber, S. and Grimm, C. (2016) Effects of freshwater Synechococcus sp. cyanobacteria $\mathrm{pH}$ buffering on $\mathrm{CaCO} 3$ precipitation: Implications for $\mathrm{CO} 2$ sequestration. Appl. Geochem. 75, 76-89.

Obst, M., Wehrli, B. and Dittrich, M. (2009) CaCO3 nucleation by cyanobacteria: laboratory evidence for a passive, surface-induced mechanism. Geobiology. 7, 324-347.

Penman, D. E., Caves Rugenstein, J. K., Ibarra, D. E. and Winnick, M. J. (2020) Silicate weathering as a feedback and forcing in Earth's climate and carbon cycle. Earth-Science Reviews. 209, 103298.

Price, G. D., Badger, M. R., Woodger, F. J. and Long, B. M. (2008) Advances in understanding the cyanobacterial $\mathrm{CO} 2$-concentrating-mechanism $(\mathrm{CCM})$ : functional components, $\mathrm{Ci}$ transporters, diversity, genetic regulation and prospects for engineering into plants. Journal of Experimental Botany. 59, 1441-1461.

Riding, R. (2006) Cyanobacterial calcification, carbon dioxide concentrating mechanisms, and Proterozoic-Cambrian changes in atmospheric composition. Geobiology. 4, 299-316.

Schlesinger, W. H. and Bernhardt, E. S. (2013) Chapter 5 - The Biosphere: The Carbon Cycle of Terrestrial Ecosystems. Biogeochemistry (Third Edition) (Schlesinger, W. H. and Bernhardt, E. S. eds.), 135-172, Academic Press.

Schott, J., Pokrovsky, O. S., Spalla, O., Devreux, F., Gloter, A. and Mielczarski, J. A. (2012) Formation, growth and transformation of leached layers during silicate minerals dissolution: The example of wollastonite. Geochim. Cosmochim. Acta. 98, 259-281.

Schubert, W.-D., Klukas, O., Krauß, N., Saenger, W., Fromme, P. and Witt, H. T. (1997) Photosystem I of Synechococcus elongatus at $4 \AA$ resolution: comprehensive structure analysis. Journal of Molecular Biology. 272, 741-769.

Spreitzer, R. J. and Salvucci, M. E. (2002) RUBISCO: Structure, Regulatory Interactions, and Possibilities for a Better Enzyme. Annual Review of Plant Biology. 53, 449-475.

Stumm, W. and Morgan, J. J. (1996) Aquatic Chemistry. Wiley Intersciences

Weber, S. and Martinez, R. E. (2017) Effects of Synechococcus sp. cyanobacteria inert biomass on olivine dissolution: Implications for the application of enhanced weathering methods. Appl. Geochem. 84, 162-172. 
385

386 
387 Table 1 Bulk composition of basaltic glass

\begin{tabular}{llr}
\hline Element & Unit & Concentration \\
\hline $\mathrm{SiO}_{2}$ & $\%$ & 47.49 \\
$\mathrm{Al}_{2} \mathrm{O}_{3}$ & $\%$ & 14.06 \\
$\mathrm{Fe}_{2} \mathrm{O}_{3}$ & $\%$ & 13.51 \\
$\mathrm{MgO}$ & $\%$ & 9.38 \\
$\mathrm{CaO}$ & $\%$ & 11.62 \\
$\mathrm{Na}_{2} \mathrm{O}$ & $\%$ & 1.85 \\
$\mathrm{~K}_{2} \mathrm{O}$ & $\%$ & 0.28 \\
$\mathrm{TiO}_{2}$ & $\%$ & 1.53 \\
$\mathrm{P}_{2} \mathrm{O}_{5}$ & $\%$ & 0.17 \\
$\mathrm{MnO}$ & $\%$ & 0.2 \\
$\mathrm{Cr}_{2} \mathrm{O}_{3}$ & $\%$ & 0.086 \\
\hline
\end{tabular}

389 
392 Table 2 Composition of flow through reactors initial solution for AFT experiment.

\section{L of active cyanobacteria stock}

\begin{tabular}{lc}
\hline Reagent & Quantity \\
\hline aliquot BG-11 & $10 \mathrm{~mL}$ \\
Synechococcus sp. & $20 \mathrm{~mL}$ \\
at the stationary phase & $0.04 \mathrm{~mol} / \mathrm{L}$ \\
$\mathrm{NaNO}_{3}$ & $0.003 \mathrm{~mol} / \mathrm{L}$ \\
$\mathrm{MgSO}_{4}$ & \\
& \\
\hline $\mathrm{Basaltic}$ glass & "Inorganic" stock \\
$\mathrm{NaNO}_{3}$ & $0.04 \mathrm{~mol} / \mathrm{L}$ \\
$\mathrm{MgSO}_{4}$ & 0.003 mol/L
\end{tabular}

393 
395 Table 3 Composition of flow through reactors initial solution for CFT experiment.

\begin{tabular}{lc}
\hline & 5 L dead cyanobacteria "autoclaved" stock \\
\hline Reagent & Quantity \\
\hline Active cyanobacteria "autoclaved" & $60 \mathrm{~mL}$ \\
$\left(20 \mathrm{~min}\right.$ at $\left.121^{\circ} \mathrm{C}\right)$ & $0.04 \mathrm{~mol} / \mathrm{L}$ \\
$\mathrm{NaNO}_{3}$ & $0.003 \mathrm{~mol} / \mathrm{L}$ \\
$\mathrm{MgSO}_{4}$ & \\
& \\
\hline $\mathrm{CaCl}$ & $0.09 \mathrm{~mol} / \mathrm{L}$ \\
$\mathrm{NaNO} 3$ & $0.04 \mathrm{~mol} / \mathrm{L}$ \\
$\mathrm{MgSO} 4$ & $0.003 \mathrm{~mol} / \mathrm{L}$ \\
& \\
\hline
\end{tabular}




\section{Figure captions}

Figure 1 Schematic interpretation of optimal conditions leading to cyanobacteria induced biomineralization in presence of basaltic glass.

Figure 2 Active cyanobacteria Flow Through open reactor (AFT) experimental set up.

Figure 3 Calcium Flow Through reactor (CFT) experimental set up.

Figure 4 Evolution of $\mathrm{pH}$ and total alkalinity through time experiment $\left(0.04 \mathrm{~mol} / \mathrm{L} \mathrm{NaNO}_{3}\right.$; AFT experiment 2). Experiment was duplicated between 0 and $120 \mathrm{~h}$.

Figure 5 Evolution of saturation index through time experiment $\left(0.04 \mathrm{~mol} / \mathrm{L} \mathrm{NaNO}_{3}\right.$; AFT experiment 2).

Figure 6 Evolution of $\mathrm{pH}$ and total alkalinity through time experiment $\left(0.04 \mathrm{~mol} / \mathrm{L} \mathrm{NaNO}_{3}\right.$; CFT experiment).

Figure 7 Evolution of Saturation index through time experiment $\left(0.04 \mathrm{~mol} / \mathrm{L} \mathrm{NaNO}_{3} ; \mathrm{CFT}\right.$ experiment). 


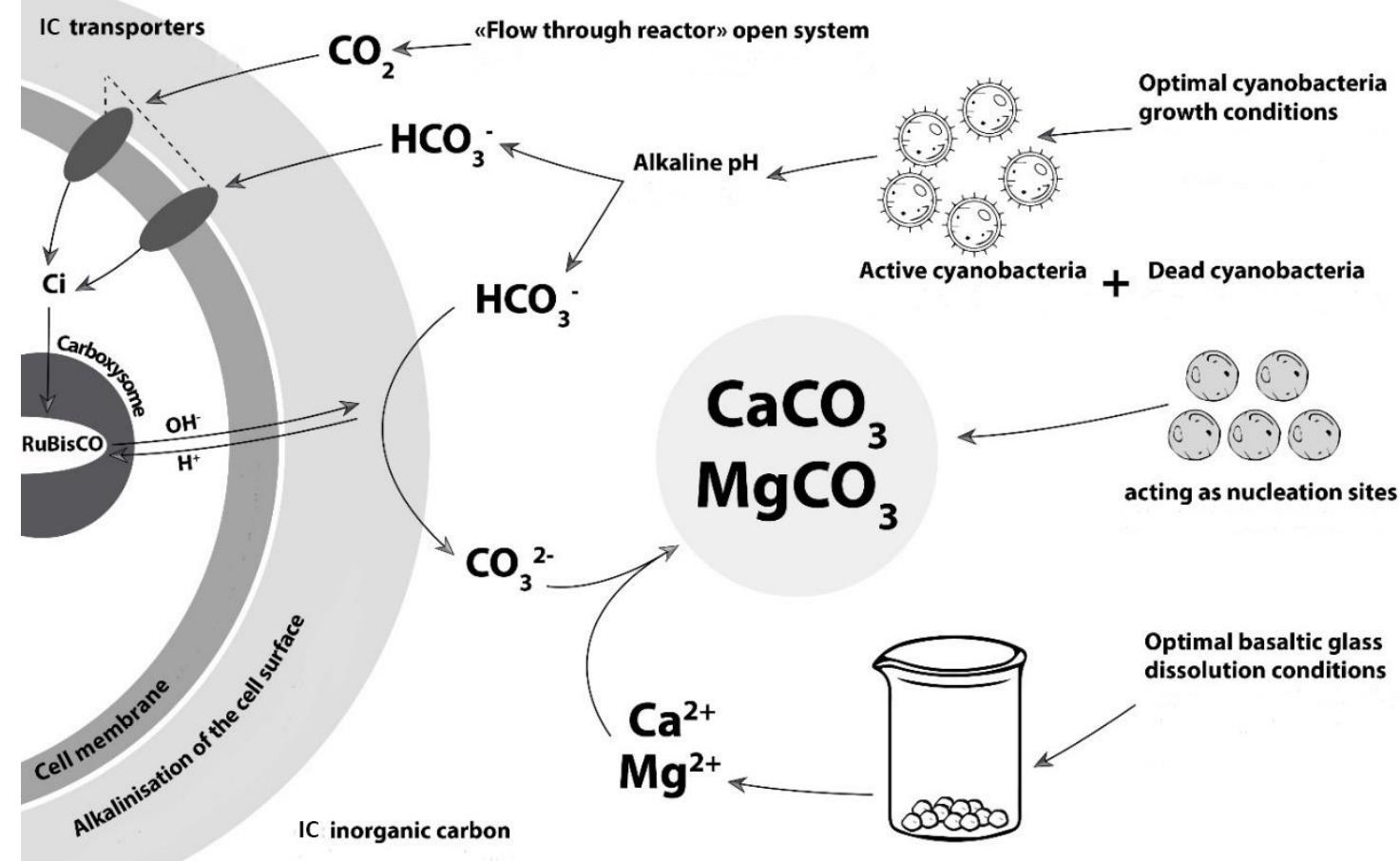

Figure 1 


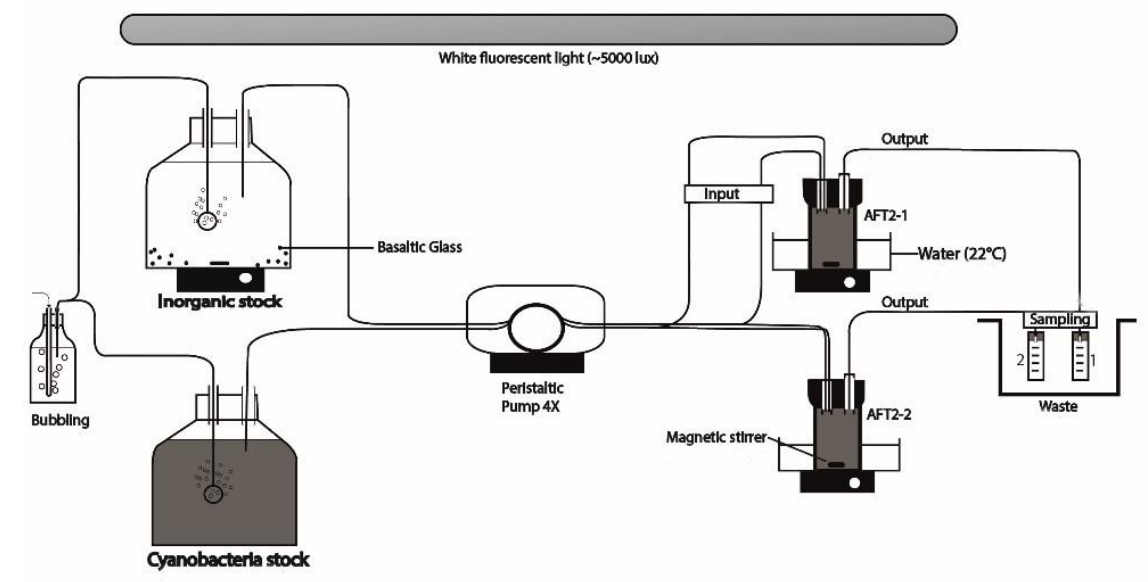

Figure 2 


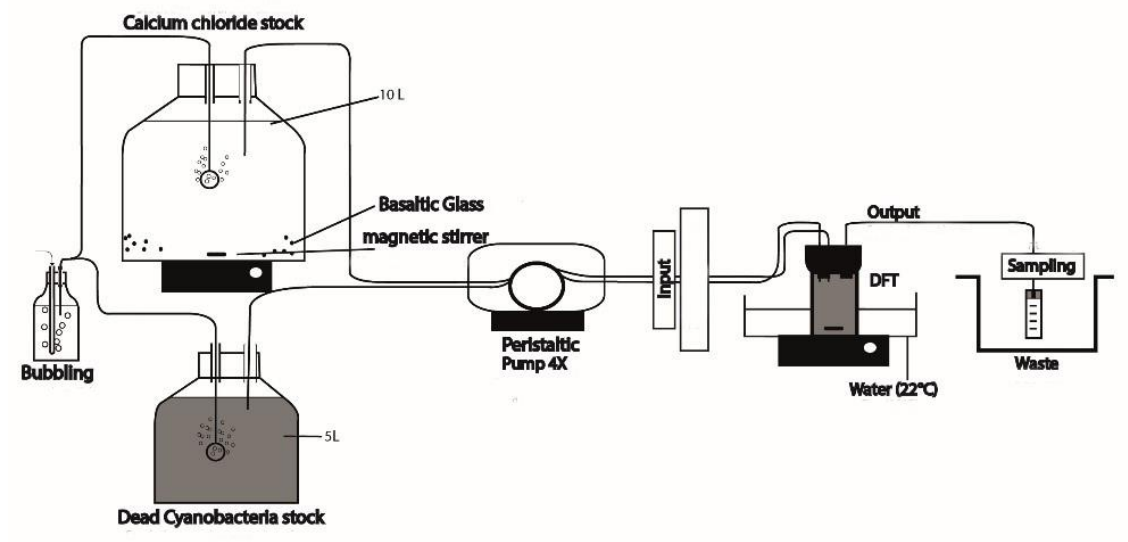

Figure 3 


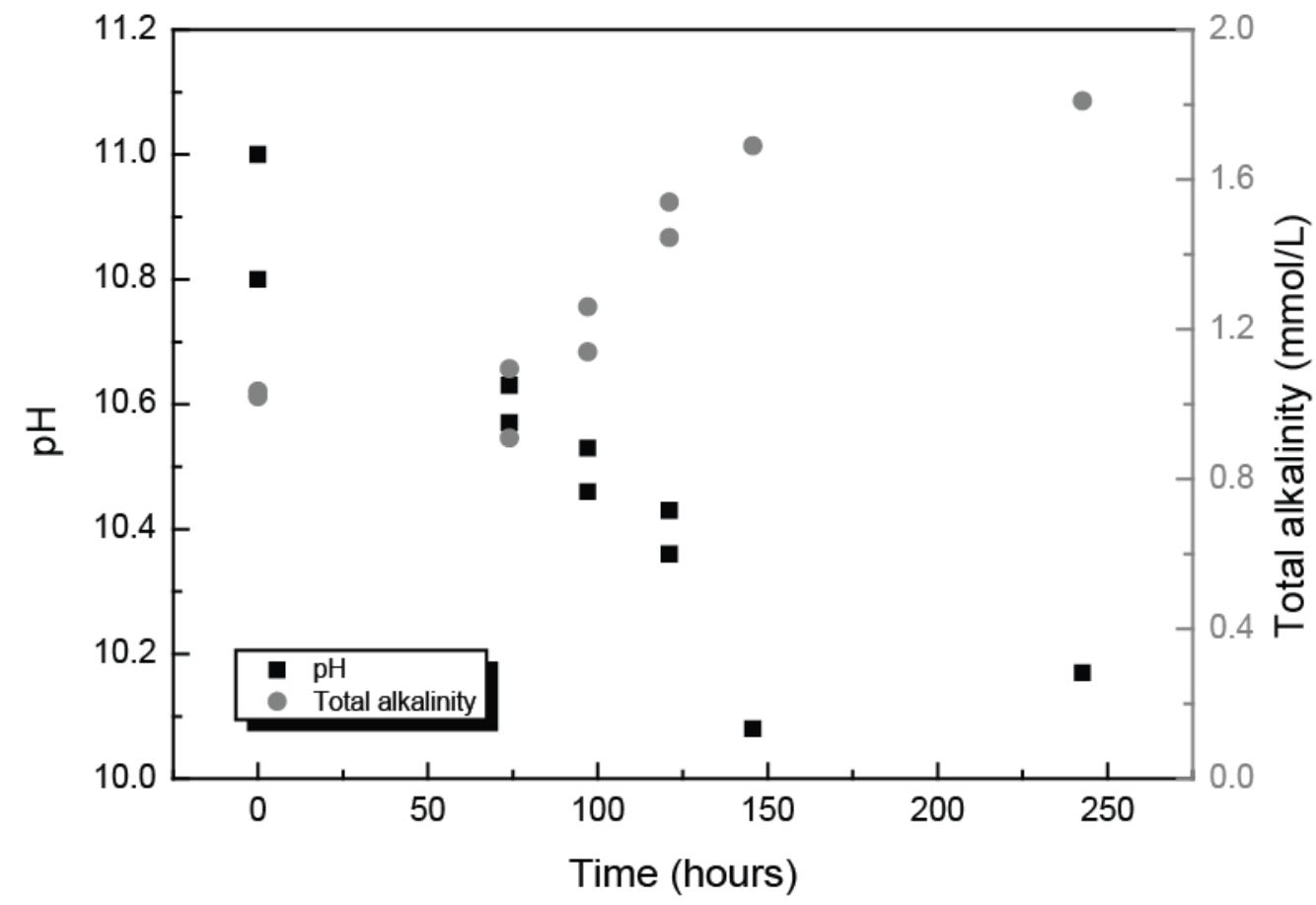

Figure 4 


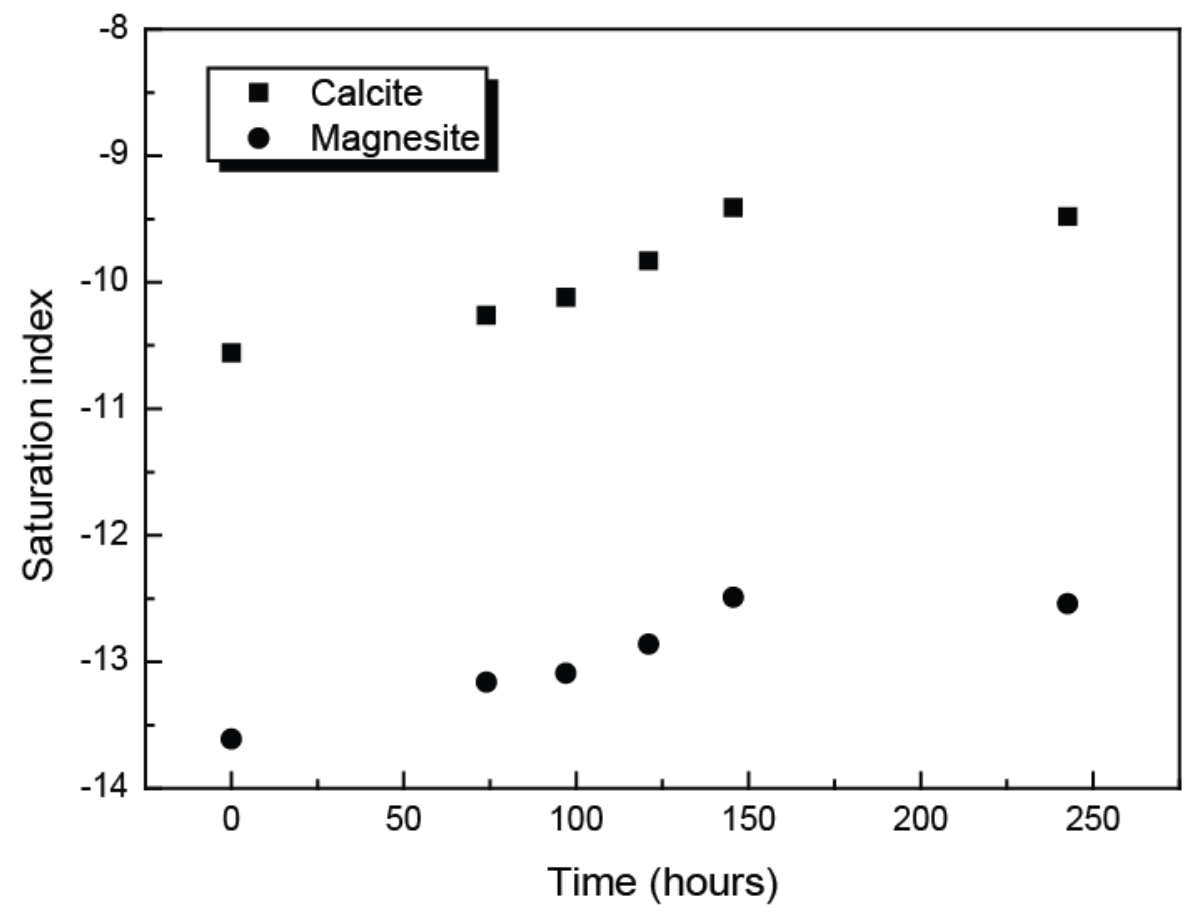

Figure 5 


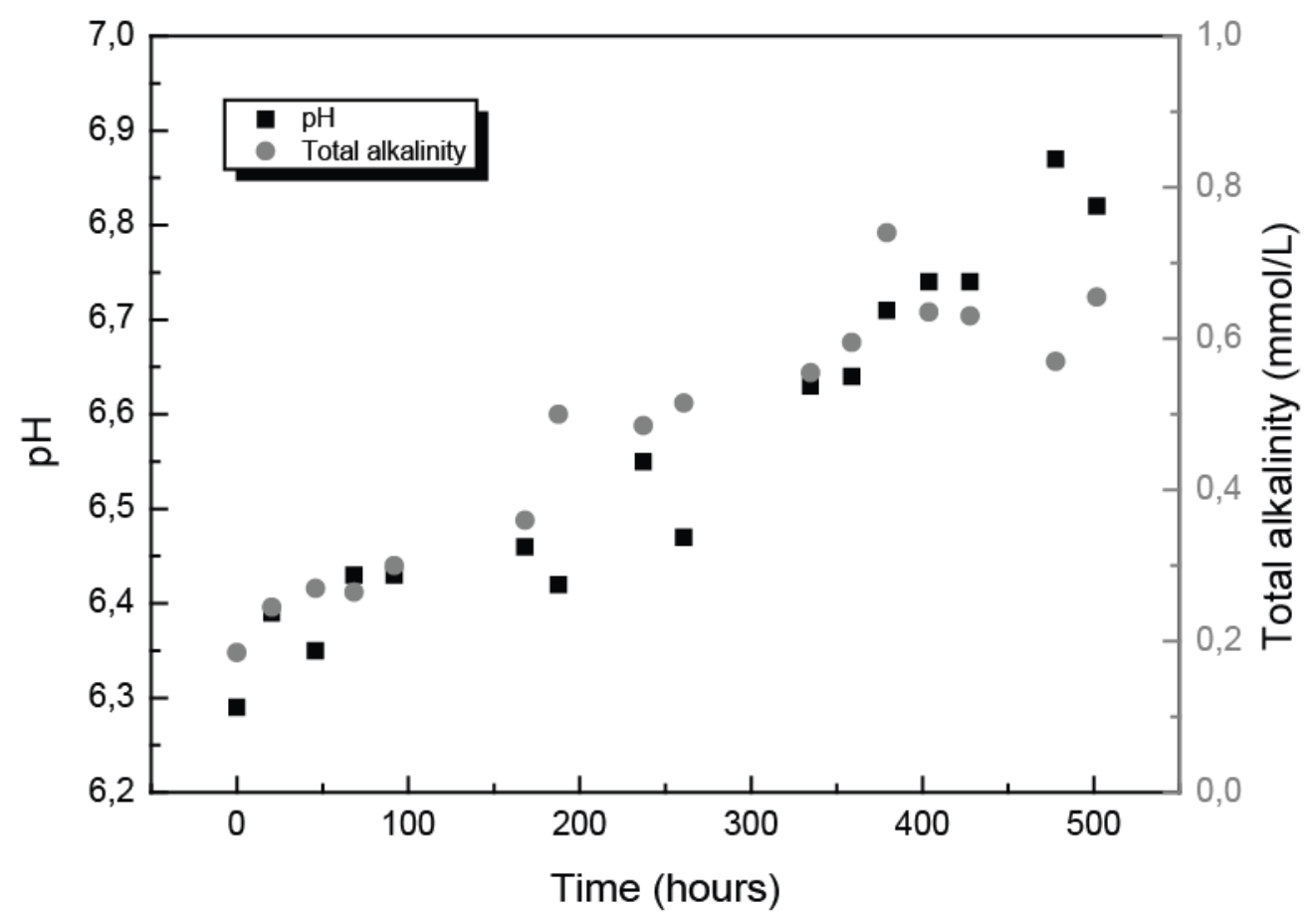

Figure 6 


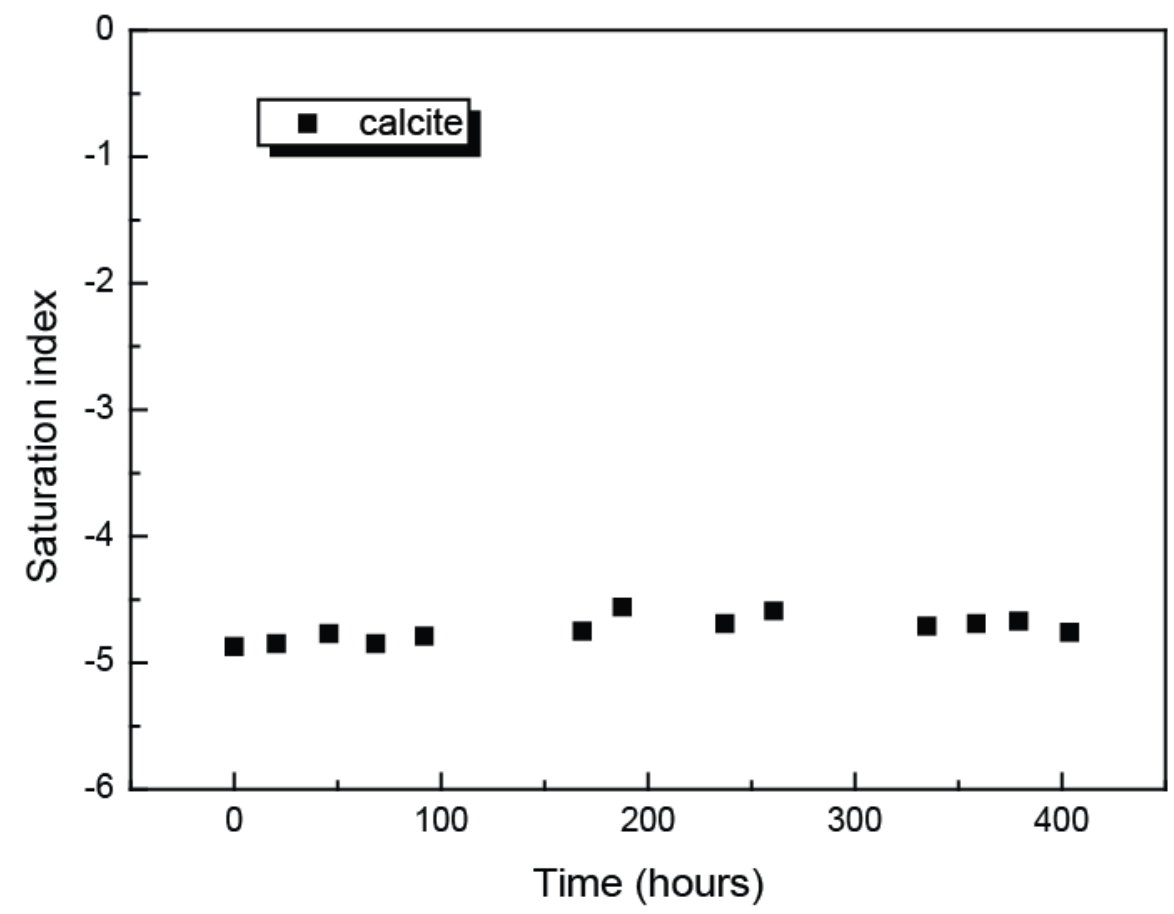

Figure 7 